\title{
Globalization and Aid from African Perspective: A Critical Review
}

\author{
Temesgen Lemessa
}

Jimma University

\begin{abstract}
Document Analysis was conducted as the main source of the review. The scholarly written works on Globalization and Aid were checked and counter checked from different perspectives. Finally the conclusion that suggests unless African countries manage the disadvantages of Globalization and aid, they could be indulged in to socioeconomic and political problems was forwarded.
\end{abstract}

Keywords: Globalization, Aid, African Perspective

\section{Introduction}

The inception of global market has passed through different stages in various forms. The notion of global market is related with getting market to sell manufactured commodities and to buy raw materials. It can be traced back historically to colonial period with strong venture from Europeans side. It was completely force driven motive to the non-western countries in general and to the countries of Africa, Asia and Latin America in particular. At that time the colonizers used the $3 \mathrm{c} \mathrm{s}$ (Christianization civilization and commerce).

To accomplish these objectives they used the works of missionaries and anthropologists, who studied the overall culture of these non-western countries. It was greedy need for economic and political supremacy that gradually transformed to globalization. In the globalized economic order the westerners could engulf the world through systematized and internationally endorsed legal system. The root of these binding legal provisions is the socio- economic and cultural system of the Euro-Americans. The other countries indifferently submit to this unfair relationship to sustain their ruling system in their home.

\section{Global Market}

Global market is slightly international market is concerned with creating free market in which complete globalization take place. In this respect, states serve as agents of change, and work for market integration. Globalization is by far more complex in content and system of implementation than a simple concept of global market which is entirely linked to commercial activities ( Manferd,B. 2000 ). It is the process of intensification of economic, political, social and cultural relations across international boundaries. It is aimed at creating homogenized world in terms of economic, political and cultural settings.

Globalization is a contestable concept among different scholars especially in relation to its pros and cons .Grieco and Holmes argued that globalization is entirely driven by the motive and interest of the Western Europe and America. Furthermore, Manfred B citing American political theorist Benjamin Barber writes destined the move of globalization is cultural imperialism which attempts to transform the world population in to blandly uniform market. But Robertson cited in Manfred, B. refuted the notion of cultural homogenization thesis and provoke the view of globalization. This is a complex process of interaction of the global and local cultures.

However, some scholars argue that the issues of globalization are critically important for the whole future economic growth and well being of people for all on the glob (Bourguignon and etal 2002). The claim of these scholars is that it not only the developed countries who earn from globalization but also the Least Developed countries could benefit from the global economy.

Globalization is much more than an economic phenomenon; the technological and political changes that derive the processes of economic globalization have intense and massive non-economic consequences. In this regard Anthony Gidden (2002) says that it is in many respects not only new revolutionary but globalization is a political, technological, cultural as well as economic integration of the world. At its grass root level, globalization is stretched to individual people in once own country.

The residents of one country have more likely been changed now than they were fifty years ago. They begun to consume the product of another country, to earn income from other countries, to make communication with the citizens of other countries, to know they are being affected by economic development in other countries and the development undertaking in other countries.

Many participants also noted that the market is by no means the panacea for the central problems that the majority of the population in developing countries is facing. In this scenario the economic, military, political and cultural predominance of Euro- Americans became apparent at its macro- level in all developing countries (Gidden, 2002). Many oppose globalization by arguing that the opening of their market would make their own country a supermarket of foreign goods which gradually can demolish locally produced goods.

Likewise, they worry that the disparity between the rich and the poor could be widened and this in turn lead the majority of the people continue to suffer in poverty (David Bigman,2002)

\section{Volume 4 Issue 11, November 2015}




\section{International Journal of Science and Research (IJSR) \\ ISSN (Online): 2319-7064 \\ Index Copernicus Value (2013): 6.14 | Impact Factor (2014): 5.611}

Alberto Arce and Norman Long (2000) said that the commodity in the free market may set off a number of significant cultural transformations. For this homogenous or unitary concept of culture often labeled certain cultural behaviors and sentiments as a tradition and embrace theoretically the central issues cultural repertoires heterogeneity and hybrid. The concept of cultural repertoire is the ways in which various cultural ingredients: (value notions, types and fragments of discourses, organizational ideas, symbols and ritualized procedures) are used and recombined in social practice, consciously.

Heterogeneity points to the generation and co-existence of multiple social forms within the same context or same scenario of problem-solving which offer alternative solutions to similar problems. But the cultural impact of globalization would gradually lead to the emergence of single global culture. The speedy flow of commodities, and information to the wide sphere of the world, would facilitate the eradication of cultural differences. The open market, free enterprise system, advertizing and the free flow of information will force the indigenous people to abandon their indigenous culture, values, ideologies and their own preferences. This will escalate cultural homogenization ( Gary Ferraro and Susan Andreatta,2010).

Donor countries donate not only their finance but also their language, culture and ideology. The transaction of commodities, rapid movement of people in the globalized world and the convergence of ideas in the global market serve the powerful countries to establish their hegemonic position in every corner of the world. In these due processes of time poor countries suffer from identity crisis from where they could not recover. Thus developing countries should be conscious of the impact of globalization on their culture, tradition, thought and language.

Likewise underlining that living cultures are necessarily multiple in the way in which they are enacted. These cultures subsume each other to form holistic existence in a given society. According to the view of this scholar globalization is perceived as threat for the growth of local industries which could serve as base for further indigenous industrial development in poor countries. Similarly for Obadina (1982) globalization is not opportunity for the poor rather it is a threat .It is an attempt to justify slavery and colonization by the western countries. Thus globalization is considered as instrument of sustaining the preponderance of the developed countries and developing underdevelopment in the third world countries.

Huntington cited in Richard Peet and et al (2009: 115) commented that globalization could be the source of ideological or economic conflict in the globalized world .He further mentions that it leads to intense division among humankind in cultural endowment. The economic progress and the social changes that came as a result of globalization led to separation of people from their previous long standing natural and local setting. The explanation of Huntington is emphasizing on the identity and cultural crises that emanate from the overall change resulted from global development.
There is also hot debate that globalization intensify environmental pollution, commercialization of culture and language, cross border migration of people, the spread of drugs and narcotics, the emergence of social and political protest in different countries ( Robert K. Schaeffter 2003:1).

Globalization remove any barrier between different countries and clear the way for the speedy fellow of ideas, goods, people and money ( Dicken cited in Kattie Willis 2005). In to this Dicken used technical concept "the shrinking world ${ }^{\text {ee }}$.

This scholar emphasized on how far the removal of restrictions and barriers of free movement of goods ideas and peoples reduce the physical abstract gap between states. When he says the shrinking world, he means that world became smaller in abstract way than ever before.

In facilitating the globalization processes, the development of the transportation and communication technology have a vital place. These developments have magnified political, social, cultural and economic activities to large scale (Willis 2005). These include the rule of law, protecting private property.

As noted by Dos Santos cited in Willis explains that globalization of the world market makes countries prone to capital flight and financial faller and this problem was observed in some countries in 1980s. It was during this critical economic problem that the giant financial institution IMF began to impose the restructuring principle based on neoliberal doctrine. This doctrine stresses the restrictive intervention of government and self regulating, flexible and free market.

\section{The International Aid}

Understanding of aid needs to examine the context of aid trends in international development assistance over the past decades. There is also a move to explore some of the challenges facing officials of donors and non -government organizations (NGOs) in ensuring that poverty reduction and participatory development become a hallmark rather than a cliché of development assistance program ( Gerard Mc.StephenMc,2003). Thus the problematic side of aid is not only for donor countries but also the recipient countries. Both countries face challenges from its practices in long run as well as short run in their own internal affairs.

The base of International aid policy is to endorse globalization as the processes of economic, political freedom and poverty reduction. But the fact on ground in developing countries depicts that free trade is linked to growing inequality than the gains in income and welfare for the poor (Ricardo cited in David Mosse and D.Lewis 2005). International aid mainly runs for the advantage of the donor's countries than the recipient countries. This is owing to the negative trade balance on the side of the developing countries. These countries will become the place where the developed countries damp their debt that will be paid by the future generation. 


\section{International Journal of Science and Research (IJSR) \\ ISSN (Online): 2319-7064}

Index Copernicus Value (2013): 6.14 | Impact Factor (2014): 5.611

The view of this scholar is that even though the developed countries claim to justify for their globalization shift by cunningly assumption that it helps to narrow the inequality of any aspects among nations of the world and the citizens of the world, it is unworkable reckoning. Aid is also criticized for it projectiles the development process in to individual projects, this undermined bilateral aid between countries. The aid is emergence driven and in some cases it has provided a veil over the lack of political action defend the causes of crises (Gerard McCann and Stephen Mc, 2003).

According o David Mosse, globalization in relation to international aid policy is based on three critical issues. First is International policy is not a product of democratic process. It produced based on the interest of donor countries. These donor countries led by US used World Bank and IMF to put their willing in to practice. Secondly the set universal principles such as international standards of governance, the financial guide lines and bench marks are all based on the interest of selected countries. It was argued by Soederberg cited in Mosse that Free market based solutions are institutionally underpinned and socially engineered. This is to ensure the emerging markets will develop in a legal, political and economic environment embedded in AngloAmerican behavioral norms and suited to Western investors while subjugating the other countries under capitalism.

The analysis of Susanne Soederberg is that IMFes international standards to regulate market behavior and manage financial liberalization and specifically the standards of ,corporate governance shows that there should be one particular social form of ,corporate governance ${ }^{\text {ee }}-$ of Anglo-American. It excluded other internal and indigenous issues in relation to governance and financial management. This principle undermined the legitimacy of alternative business culture. Thus it is an imposition of Euro-American governance and business culture.

This scholar further argues that the market-centric focus on ,shareholder value ${ }^{e e}$ involved in the chosen model serves the interests of US institutional investors. This included pension funds, insurance companies, bank trusts, mutual funds increasingly looking to higher-risk, higher-profit foreign investment. These donor countries dominated other policies such as, water policy, trade or property rights, in which global policy can also be viewed as built upon selected national or corporate interests.

The new global aid frame works suggests that they involve an unprecedented level of intervention and social engineering in developing countries. Soederberges work on standard points to the disciplining of emerging markets through intrusive regimes of surveillance that monitor practices in public and private sectors against ,universal principles $^{\text {ee }}$ while constructing a reality around their own interest of free capital mobility. Scholars such as Anders and Gould argue that external controls of conditionality under structural adjustment program (SAPs) to the internal discipline and governance is increasing.

They said this "a shift from hard to soft conditionality". This brought increased power of surveillance and control over sovereign states and more invasive monitoring of liberalization. The liberalization policy is aimed to remove any set back against the financial flow of these donor countries in the recipient countries. In the aid recipient countries; multifarious problems began to control their home in different aspects. The huge amount of Euro- American dollar which had been damped on the developing countries created huge debt which finally developed in to debt crisis.

It was reported that in 1980 s some aid recipient countries openly declared that they couldn't pay back the dollar which they received from different loan donating banks for example Poland, Romania, Mexico Latin American and African countries. It was the first debt crisis in the history of nations (Robert K. 2003). Banks in Western Europe and North America reached on the brink of collapse and the economic atmosphere stated to sense bankruptcy. Financial chaos and economic depression was knocking the door of their economy. To solve these problems, the northern creditors and their financial institutions (IMF and World Bank) demanded that the southern borrowers should adopt strenuous economic reforms to repay heir debit.

The main solution forwarded by these financial institutions was making their economic policy along the neoliberal lines (Robert K., 2003:97).But this policy aggravated the problem prevailing in the recipient countries. The IMF and the World Bank persuaded countries to follow their foot step on the line of neoliberal policy by using their aid and donation. This neoliberal policy needs new rules and regulations, especially in relation to their domestic economic affairs. These regulations include removal of subsides, any man made trade barriers between nations, economic privatization, decreasing the value of their currency and opening their door for massive investment(Ted C.Lewellen,2003).

The structural adjustment program formulated by the IMF and World Bank created internal economic problems in many countries. It was considered as challenge for sustainable and consolidated reform in many African countries and peoples of these countries opposed the implementation of structural adjustment programs in their countries.

The imposition of Structural Adjustment program on the aid recipient countries aggravated poverty intensified environmental destruction and decline of government services. The economic well being of these countries lost support from their government due to the restriction on the intervention of the government in the economic sector. The government was restricted by the structural adjustment program not to play its role in the economy and delivering services for the people. This was the reason for the prevailing strikes and riots against the implementation of SAPs in different countries.

Politically, there is scholarly debate that aid in the wake of globalization had/have negative impact on the political system of developing countries in general and African countries in particular. Many years experience of loans and aids from western countries have negatively affected the political reform of the recipient countries. The aid diminished states power to decide on their internal economic 


\section{International Journal of Science and Research (IJSR) \\ ISSN (Online): 2319-7064}

Index Copernicus Value (2013): 6.14 | Impact Factor (2014): 5.611

issues. Even the world had begun to question about the assistance given to the developing countries through IMF and World Bank (Arthur A. Goldsmith,2001)

He argued that it is a harmful incur on the political and development system of Africa.

In the same way Tim Murithi in Hakima and Yves (2009) argues that the international legal institutions perpetuated the exploitative relationship between the developed and developing countries. The policies of the IMF has generated and propagated underdevelopment in Africa in other developing nations. The World Bank and the IMF were under the sole control of the world 's wealthiest nations and hence voting on policy implementation is weighted according to the capital shares that each nation owns. Consequently the representatives of these wealth countries use their influence to make policies that satisfy the interest of the rich countries at the expense of the poor countries.

\section{Conclusion}

Global market and globalization are machines established and institutionalized by Euro-Americans to widen their economic, political and cultural hegemony over the world.

The issues of global market and globalization entrenched through trade rules and regulations which were endorsed by the developed countries. These regulations and rules were coined by the western world so as to superimpose their interest.

Trade rules and regulations were aimed at removing barriers against the free movement of trade activities among countries. Developing countries accepted these issues through unbalanced trade treaties and agreements. International aid played a key role in facilitating global trade and globalization and it also became a guarantee for the Euro-American economic, political and cultural predominance over the world. For the developing countries it is a knot that keeps them under the economic and political supremacy of the developed countries.

\section{References}

[1] Abbas ,Hakima and Niyiragira Yves (2009). Aid to Africa Redeemer or Colonizer? Pambazuka press, Cape Town, Dakar Nairob, and Oxford

[2] Alberto Arce and Norman Long (2000), Anthropology, Development and Modernity: Exploring Discourses counter-tendencies and violence. London and Routledge New York

[3] Bigman, David ( 2002). Globalization and the Developing countries: Emerging Strategies for Rural Development and Poverty Alleviation. CABI pub.

[4] Bourguignon, Francois et al (2002)). Making Sence of Globalization: A Guide to the Economic Issues Centre for Economic policy Research, London, CEPR policy paper No 8

[5] Ferraro, Gray and Andrea Susan Andrea .2010). Cultural Anthropology: An Applied Perspective. Wadsworth, Cengag Learning
[6] Giddens, Anthony .2002. Runaway World: How Globalization is reshaping Our Lives. London: profile Books.

[7] Grieco,M, and Holems,L.1999. Tell options for Community Business: an opportunity for economic growth in Africa" Africa Notes.

[8] Goldsmith, A. Arthur," Donors, Dictators and Democrats in Africa" Journal of Modern African Studies,39,3(2001),pp.411-436

[9] Mosse, David and Lewis David .2005. The Aid Effect: Giving and Governing International Development. Pluto Press, London.

[10] Obadna, T .1982. "Globalization, Human Right and development”,Africa today(October) n.d .pp. 32-33

[11] Peet, Richard and et al .2009. Theories of Development: Contentions, Arguments, Alternatives. Guilford press,New York, London

[12] Schaeffter, Robert K. 2003. Understanding Globalization: The Social Consequences of Political Economic and Environmental Change. $2^{\text {nd }}$ Edition, Rowman and Littlefield Pub. Inc.

[13] Steger, Manferd .2000. Globalization: A Very Short Introduction. Oxford, New York 